\title{
The Exhumation of the Northern Patagonian Massif Gondwana Planation Surface Due to Uprising During the Oligocene
}

\author{
Eugenio Aragón, Emilia Y. Aguilera, Claudia E. Cavarozzi, \\ and Alejandro Ribot
}

\begin{abstract}
The altiplano (or high plain) of the Northern Patagonian Massif is a large, $100,000 \mathrm{~km}^{2}$ geomorphological unit that rose from sea level to at least 1,200 metres above sea level (m a.s.l.) in Early Oligocene times, as a consequence of epeirogenic uplift. This uniform tableland feature is essentially a Cretaceous planation surface carved on Paleozoic igneous and metamorphic rocks of the Northern Patagonian Massif. This planation surface had been preserved by a thin and scattered cover of Maastrichtian-Danian marine sediments and Late Oligocene-Early Miocene basaltic flows. Erosion since Middle Miocene times at this tableland has exposed much of the Gondwana planation surface and developed numerous basaltic plateaus by relief inversion.
\end{abstract}

Keywords Altiplano • Patagonia • Plateau • Planation surface • Basalts

\footnotetext{
E. Aragón $(\varangle) \bullet$ C.E. Cavarozzi

Centro de Investigaciones Geológicas (Universidad Nacional de La Plata-CONICET), $1 \mathrm{~N}^{\circ} 644$, (1900), La Plata, Argentina
}

Facultad de Ciencias Naturales y Museo, Universidad Nacional de La Plata, 122 y 60, s/n., (1900), La Plata, Argentina

e-mail: earagon@cig.museo.unlp.edu.ar

\section{E.Y. Aguilera}

Facultad de Ciencias Naturales y Museo, Universidad Nacional de La Plata (UNLP), Calles 122 y 60, 1900-La Plata, Argentina

DAIS (Dirección de Aplicación de Imágenes Satelitarias), Calle $7 \mathrm{~N}^{\circ} 1267-2^{\circ} \mathrm{P}$, 1900-La Plata, Argentina e-mail: eaguilera@fcnym.unlp.edu.ar
A. Ribot
Facultad de Ciencias Naturales y Museo, Universidad Nacional de La Plata, 122 y 60, s/n., (1900), La Plata, Argentina

LEMIT - CIC, 52 entre 121 y 122, (1900), La Plata, Argentina 


\section{Introduction}

A Gondwana planation surface is well preserved in the extra-Andean region of Northern Patagonia, in the Northern Patagonian Massif, a tectono-morphological, geological unit. The massif is composed of Proterozoic and Early Paleozoic metamorphic rocks, intruded by Ordovician, Carboniferous, and Permian igneous bodies, followed by Triassic and Jurassic volcanic complexes. This massif was strongly eroded from the Middle Jurassic to the Late Cretaceous (Rabassa 1978; González Díaz and Malagnino 1984; Franchi et al. 1984; Corbella 1984; Aguilera 2006; Aragón et al. 2003, 2005, 2008, 2009, 2010, 2011), feeding its cover sediments into the surrounding basins. These are the Neuquén Basin to the northwest, the Colorado Basin to the northeast, the Nirihuau Basin to the west-southwest, and the Cañadón Asfalto Basin to the south (Fig. 1). A large Gondwana planation surface was then exposed as the sediments covering it were modified. This planation surface is finally covered and preserved by a thin sedimentary sequence of Late Cretaceous and Early Tertiary (Fig. 2a) continental-marine sediments (Malumián 1999) and basalts of Oligocene-Early Miocene age (Ardolino 1981; Corbella 1984; Franchi et al. 1984, and references therein).

In present times, the Northern Patagonian Massif shows a rather flat, topographic surface at an average elevation of 1,200 meters above sea level (m a.s.l.) (Coira 1979; Nullo 1978) that stands 500-700 $\mathrm{m}$ above the surrounding country and

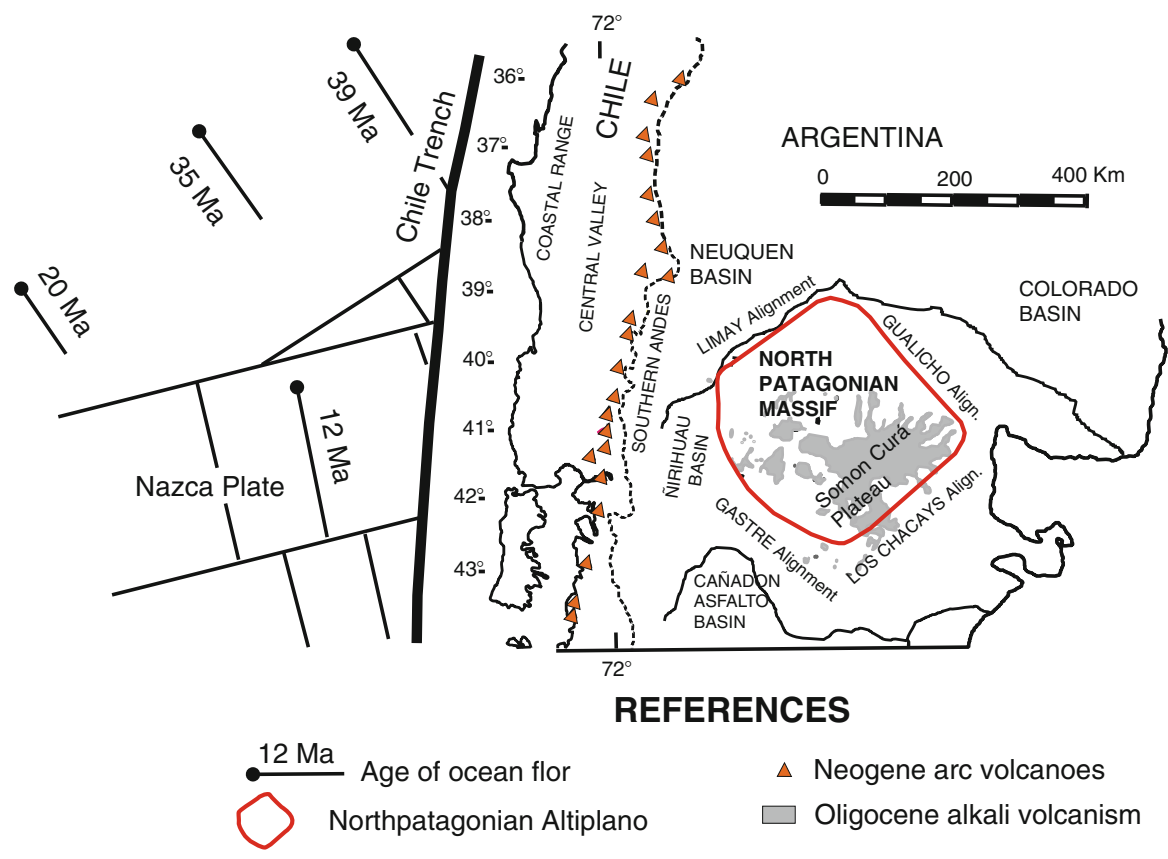

Fig. 1 Main Cenozoic geological features of Northern Patagonia 

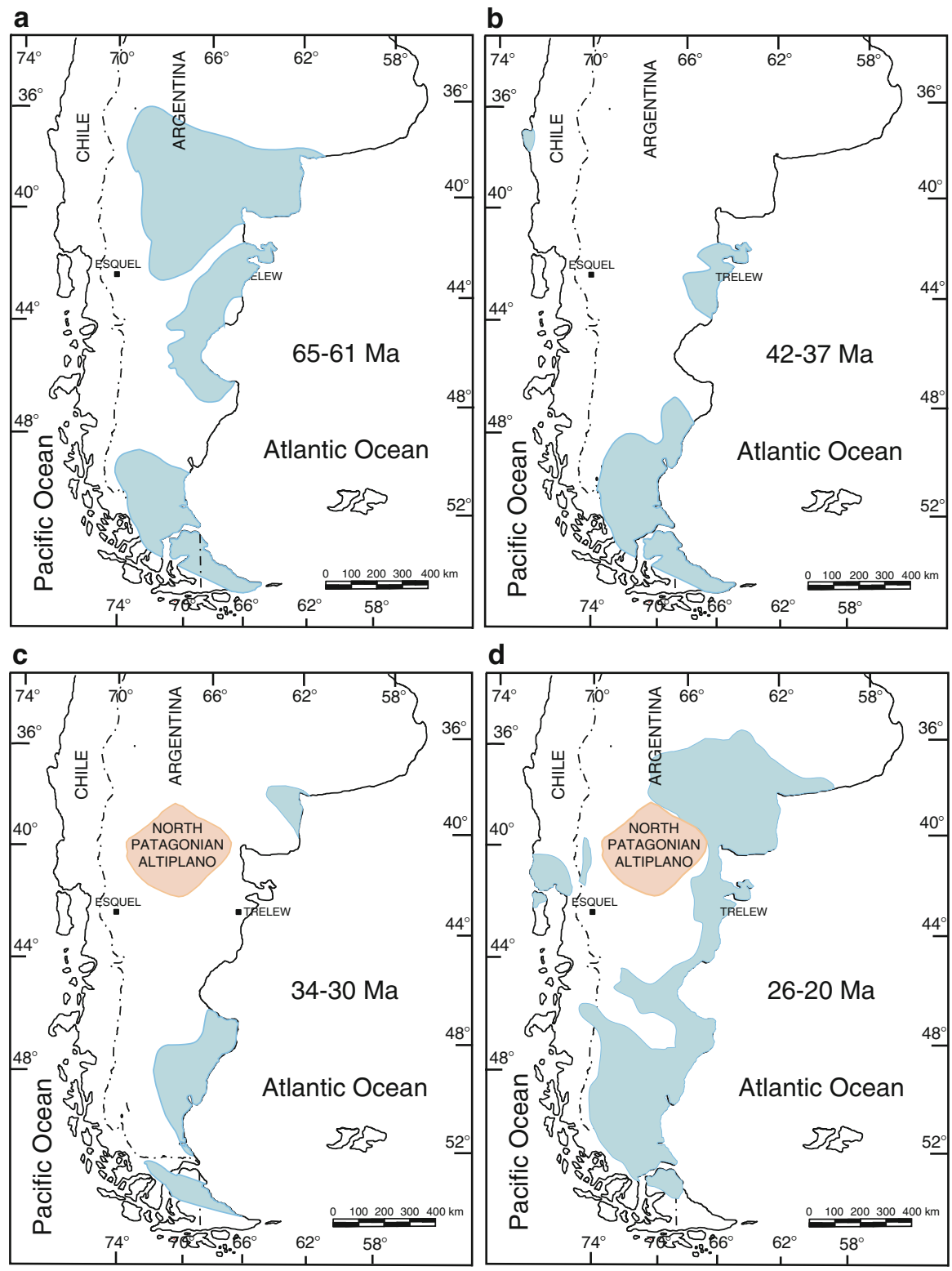

Fig. 2 Paleogeography of Patagonia, showing main Tertiary transgressions with respect to the Northern Patagonian Massif uprise: (a) Maastrichtian-Danian; (b) Eocene; (c) Oligocene; (d) Late Oligocene-Early Miocene 
peripheral rivers (the Río Chubut to the south and the Río Negro to the north), showing that this high-lying tableland is an "altiplano" or high plateau.

\section{Exhumation of the Altiplano Due to the Uplift of the Northern Patagonian Massif}

The uplift of the Gondwana planation surface from near sea level positions to 1,200 $\mathrm{m}$ a.s.l. took place in the Early Oligocene (Fig. 2c), or even in the Late Eocene (Aragón et al. 2011), as a result of epeirogenic uplift of a surface of $100,000 \mathrm{~km}^{2}$ (Fig. 1), constrained by four major alignments: the Gastre alignment to the southwest, the Chacays alignment to the southeast, the Gualicho alignment to the northeast, and the Limay alignment to the northwest.

The epeirogenic nature of the uplift is demonstrated by the presence of undeformed Maastrichtian-Danian marine sediments (Fig. 2a) that kept a subhorizontal position even at an average altitude of $1,100 \mathrm{~m}$, scattered almost all over the surface of the altiplano. Instead, the Maastrichtian-Danian marine sediments stand at altitudes that range about $300-500 \mathrm{~m}$ and show deformation, at the altiplano surrounding country rocks along the Río Chubut to the south and the Río Negro to the north.

The age constrain to the uplift of the altiplano is set by the basalt flows above the tableland. These basalts cover more than $15,000 \mathrm{~km}^{2}$ from the central to the eastern and southeastern boundaries of the altiplano (Figs. 1 and 3). The ages of these basalt flows range from the Late Oligocene to the Early Miocene (Ardolino 1981), and at the southeastern boundary of the altiplano, they spill from the altiplano edge down to the surrounding country as a cascade descending more than $500 \mathrm{~m}$, showing that the altiplano had gained much of its altitude previous to the eruption of these lava flows.

A second argument showing that the North Patagonian altiplano has remained as such with respect to the surrounding country land since Late Oligocene times is suggested from the fact that the Late Oligocene-Early Miocene transgression was not able to flood the higher areas of the altiplano (Fig. 2d).

Erosion since the Middle Miocene at the altiplano of the Northern Patagonian Massif has exposed much of the Gondwana planation surface and developed plateau basalts by local relief inversion (Fig. 4).

\section{Tectonic Setting}

The Paleogene uplift history of Northern Patagonia is related to the major plate convergence changes caused by the collision of the South America plate with the Farallón-Aluk active ridge in the Late Paleocene (Cande and Leslie 1986). 


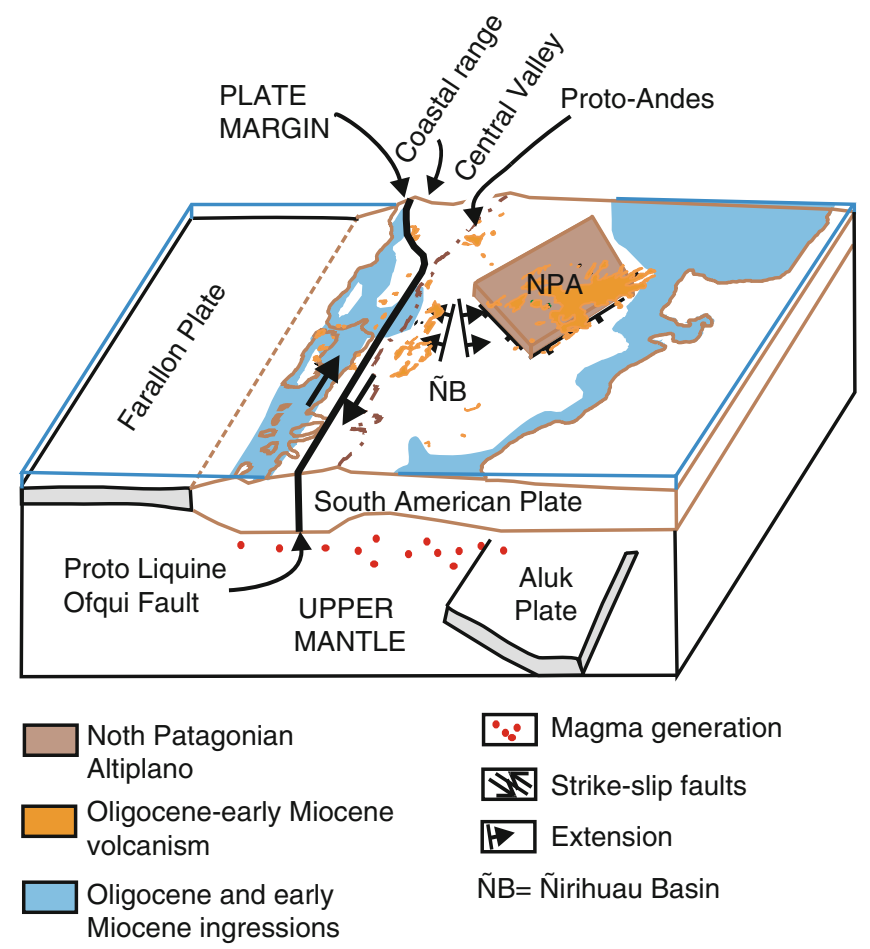

Fig. 3 Northern Patagonia 3D paleogeography and tectono-magmatic setting for the Late Oligocene-Early Miocene

The highly oblique convergence of the Farallón-SAM plates in the Paleogene was considered to have caused the development of oblique subduction (Rapela et al. 1987), but a more recent work suggests that the Aluk plate detached (Aragón et al. 2011), and the Farallón-SAM plates developed a transform margin (Fig. 3). During this time, extension has led to the development of the Nirihuau Basin (González Bonorino 1973; Rabassa 1978; Cazau et al. 1989).

In this transform plate margin setting (Fig. 3), a large slab window will develop in time, leading first to regional mantle upwelling with the development of swelling, crustal uplift (Fig. 2b), and extension, with small basins that begin to develop at the former back-arc (Nirihuau Basin). Finally, as the thermal swelling effect diminishes (Early Miocene), large transgressions from the Atlantic and Pacific oceans cover most of Northern Patagonia (Figs. 2d and 3). Then the tectonic scenario for the Northern Patagonian Massif uplift is extensional and coeval to the development of the Nirihuau Basin at its southwestern side. The apex of uplift for this plateau must have been reached in the Early Miocene, as the Northern Patagonian Massif plateau was surrounded by the Atlantic and Pacific oceans transgressions (Figs. 5 and 6). 


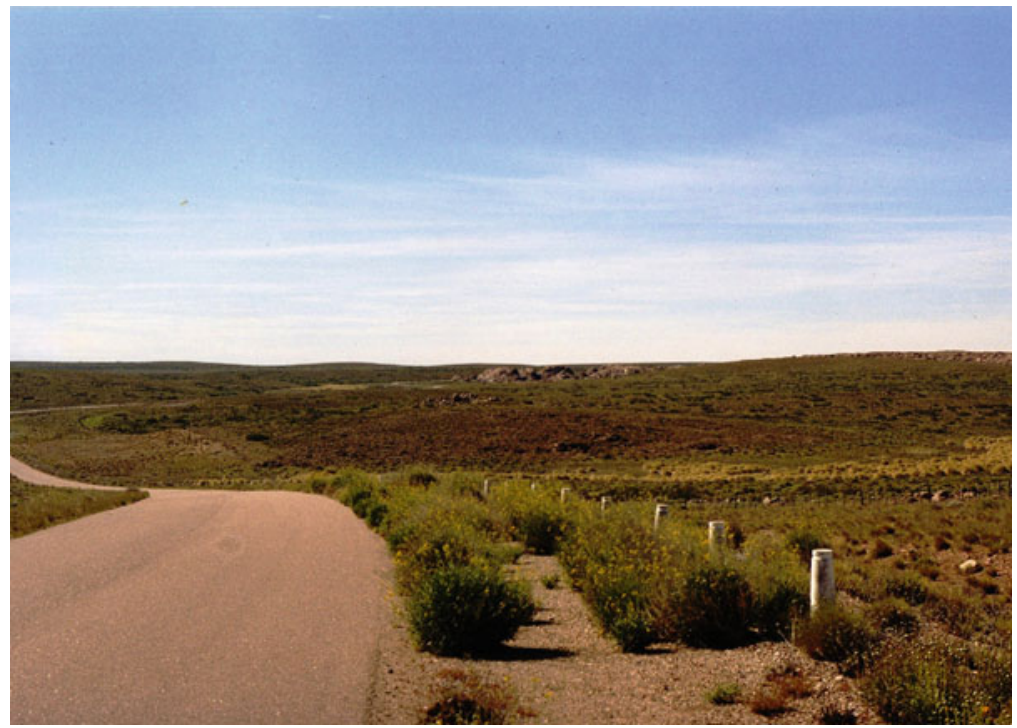

Fig. 4 Gondwana planation surface on Permian granitoid rocks at the North Patagonian Massif. A sector corresponding to the smoothly undulating, granitic plain with regolith cover. At the center of the photograph, a residual landform of the strongly eroded dome type may be observed

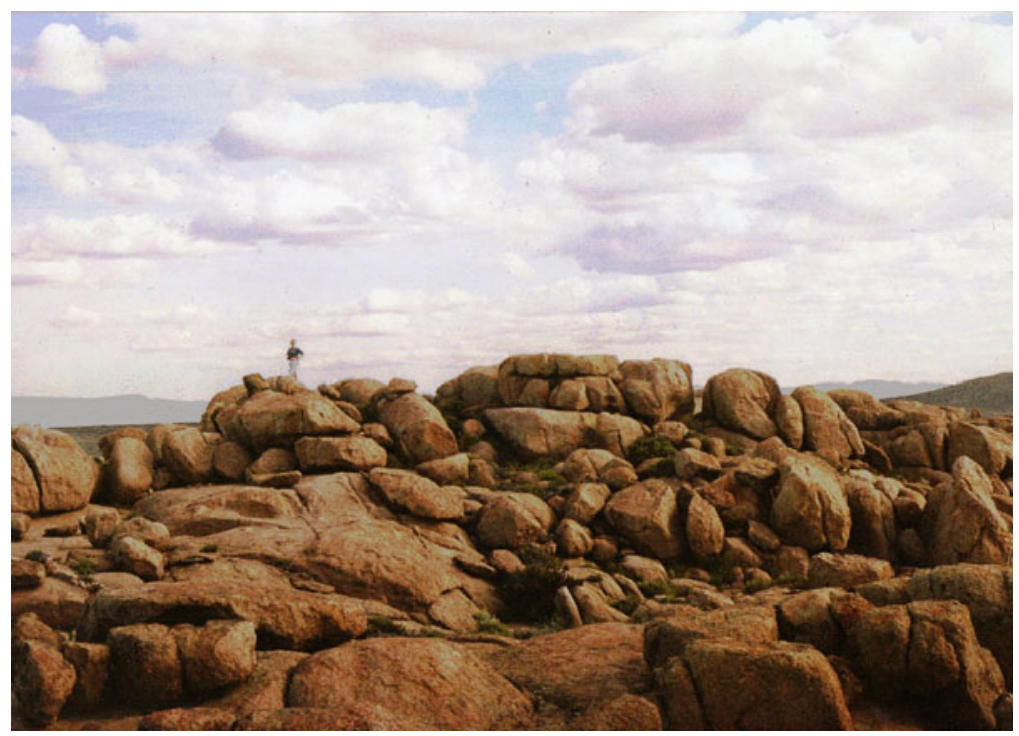

Fig. 5 A slightly convex sector of the paleosurface, corresponding to the "whale-back" type, with superficial development of severely eroded levels stressed by dominant horizontal fracturing over a much less developed vertical fracturing 


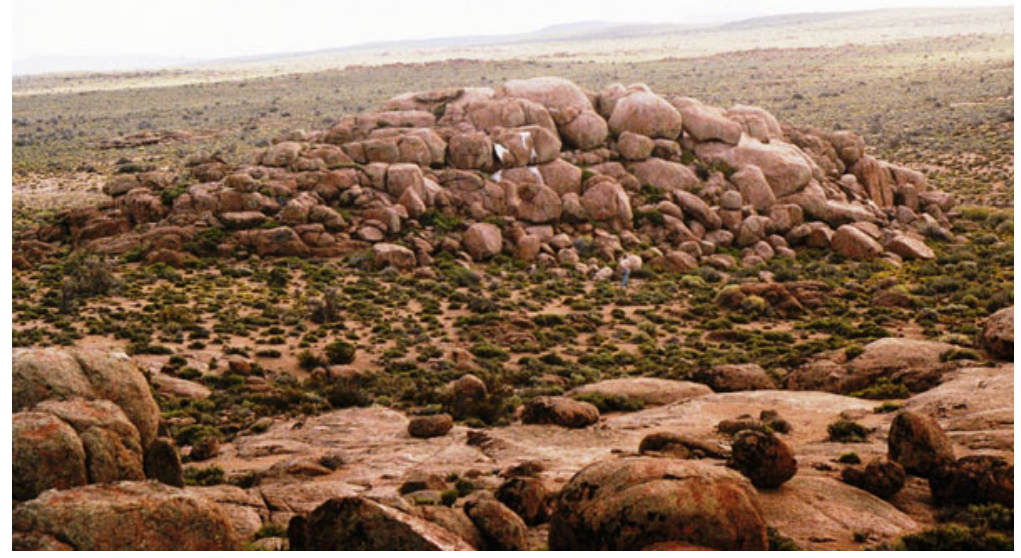

Fig. 6 A detail of the severely eroded dome which occurs isolated in the granitic platform. Rounded boulders or corestones may be also observed

\section{Concluding Remarks}

The surface morphology of Northern Patagonia has at least three well-preserved nearly level surfaces: (a) the Gondwana planation surface caused by protracted erosion from the Middle Jurassic to the Late Cretaceous times, (b) the surface of the Maastrichtian-Danian marine sediments which flooded the Gondwana planation surface, and (c) the Late Oligocene-Early Miocene basalt lava flows.

Much of the Gondwana planation surface in Northern Patagonia is now exposed at the altiplano of the North Patagonian Massif. This is the reason for the nearly level surface morphology of this uplifted cratonic area. The exhumation of the Gondwana planation surface from sea level to the present altitude of 1,200 $\mathrm{m}$ a.s.l. could have started in the Late Eocene, but the main uplift of the unit may be related to the Oligocene extensional setting and mantle upwelling caused by the detachment of the Aluk plate and the development of a large slab window (Fig. 3) (Aragón et al. 2011). It was not until the altiplano of the Northern Patagonian Massif had reached a considerable altitude that the Late Oligocene-Early Miocene basalt flows (probably related to decompression melting) covered part of the altiplano and spilled down from its edges. Finally, Neogene erosion developed plateaus above the altiplano as a consequence of relief inversion. The large extent of some of these basaltic plateaus had erroneously led in the past to the conclusion that the altiplano of the North Patagonian Massif was caused by relief inversion. The debate continued until it was demonstrated that the basalt flows were younger than the uplift. 
Acknowledgments This research was supported by the following grants: CONICET PIP 00/916 and UNLP 11/534 and UNLP 11/689.

\section{References}

Aguilera EY (2006) Identificación y distribución de distintas superficies geomorfológicas de escaso relieve local, por medio de sensores remotos en el área del Macizo Nordpatagónico, Provincia de Río Negro. Unpublished Doctoral Thesis, Facultad de Ciencias Naturales y Museo, Universidad Nacional de La Plata, La Plata, Argentina, 230 pp

Aragón E, González P, Aguilera EY, Cavarozzi C, Llambías E, Rivalenti G (2003) Thermal divide andesites-trachytes, petrologic evidence, and implications from Jurassic north Patagonian massif alkaline volcanism. J S Am Earth Sci 16(3):91-103

Aragón E, Carroll AR, Aguilera EY, Cavarozzi C (2005) Ancient Gondwana landforms in Patagonia. In: Gondwana 12, "Geological and Biological Heritage of Gondwana", Mendoza, Argentina, Abstracts, Academia Nacional de Ciencias, p 46

Aragón E, Aguilera EY, Cavarozzi C, Ubaldón MC, Ribot A (2008) La Caldera de Piedra Parada. Un volcán gigante de 50 millones de años, testimonio de cambios. In: Sitios de Interés Geológico, Ediciones Servicio Geológico Minero Argentino, Anales 46, 2, 669-682. Buenos Aires

Aragón E, Goin FJ, Aguilera EY, Woodburne MO, Carlini AA, Roggiero MF (2009) Paleogeography and paleoenvironments of Central Patagonia from the Late Cretaceous to the Miocene: the Paleogene Andean gap and the rise of the North Patagonian Altiplano, Abstracts, Workshop "Paleogeography and Paleoclimatology of Patagonia: effects on biodiversity", Universidad Nacional de La Plata-Dalhousie University-CONICET-ANPCyT- National Science Foundation: PIRE (Partnerships for International Research \& Education), La Plata

Aragón E, Aguilera EY, Cavarozzi C, Ribot A (2010) The North Patagonian Altiplano and the Somón Cura basaltic plateau. Geociências 29(4):527-532, São Paulo, UNESP, Brazil

Aragón E, Dèramo F, Brunelli D, Castro A, Rivalenti G, Varela R, Rabbia O, Spackman W, Cavarozzi CE, Aguilera EY, Mazzucchelli M, Demartis M-L, Ribot A (2011) Tectono-magmatic response to major convergence changes in the North Patagonian suprasubduction system: the Paleogene subduction-transcurrent plate margin transition. Tectonophysics 509:218-237

Ardolino A (1981) El volcanismo Cenozoico del borde suroccidental de la Meseta de Somún Curá. Provincia del Chubut. In: $8^{\circ}$ Congreso Geológico Argentino, Actas, 3, 7-23

Cande SC, Leslie RB (1986) Late Cenozoic tectonics of the Southern Chile trench. J Geophys Res 91(B1):471-496

Cazau L, Mancini D, Cangini J, Spalletti L (1989) Cuenca Ñirihuau. In: Chebli G, Spalletti L (eds) Cuencas Sedimentarias de Argentina, Correlación Geológica 6, 299-318

Coira BL (1979) Descripción geológica de la hoja 40d, Ingeniero Jacobacci: provincia de Río Negro. Servicio Nacional Minero Geológico, Carta geológico-económica de la República Argentina. Escala 1:200.000, Argentina. Ministerio de Industria y Minería, Argentina. Subsecretaría de Minería, Boletín 168, 5-99. Buenos Aires

Corbella H (1984) El vulcanismo de la altiplanicie de Somuncura. In: $9^{\circ}$ Congreso Geológico Argentino, Relatorio, 1, 10, 267-300

Franchi MB, Nullo FE, Sepúlveda EG, Uliana MA (1984) Las sedimentitas Terciarias. In: $9^{\circ}$ Congreso Geológico Argentino, Relatorio, 1, 9, 215-266

González Bonorino F (1973) Geología de la región de San Carlos de Bariloche, provincia de Río Ngero. Fundación Bariloche, Publicaciones del Departamento de Recursos Naturales y Energía, San Carlos de Bariloche

González Díaz EF, Malagnino EC (1984) Geomorfología de la Provincia de Río Negro. In: $9^{\circ}$ Congreso Geológico Argentino, Relatorio, 2, 1-159 
Malumián N (1999) La sedimentación y el volcanismo Terciarios en la Patagonia extraandina. In: Caminos R (ed) Geología Argentina. Servicio Geológico Nacional, Anales 29, 18, 557-578, Buenos Aires

Nullo FE (1978) Descripción geológica de la hoja 41d, Lipetrén: provincia de Río Negro, Carta geológico-económica de la República Argentina. Escala 1:200.000, Argentina. Ministerio de Industria y Minería, Argentina. Subsecretaría de Minería, Servicio Nacional Minero Geológico, Boletín 158, 5-89. Buenos Aires

Rabassa J (1978) Paleorrelieves Cenozoicos en la región de Pilcaniyeu-Comallo, Provincia de Río Negro. In: $7^{\circ}$ Congreso Geológico Argentino, Actas, 2, 77-87

Rapela CW, Spalletti L, Merodio JC, Aragón E (1987) Temporal evolution and spatial variation of the lower Tertiary Andean volcanism (40-42 $30^{\prime}$ S). J S Am Earth Sci 1:1-14 